\title{
Permanent Thermal and Chemical Stratification in a Restored Urban Meromictic Lake
}

\author{
Renata Tandyrak*(D), Jolanta Katarzyna Grochowska (D), Renata Augustyniak (D) and Michał Łopata (D)
}

check for updates

Citation: Tandyrak, R.; Grochowska, J.K.; Augustyniak, R.; Łopata, M. Permanent Thermal and Chemical Stratification in a Restored Urban Meromictic Lake. Water 2021, 13, 2979. https://doi.org/10.3390/w13212979

Academic Editor: Anas Ghadouani

Received: 9 July 2021

Accepted: 18 October 2021

Published: 22 October 2021

Publisher's Note: MDPI stays neutral with regard to jurisdictional claims in published maps and institutional affiliations.

Copyright: (c) 2021 by the authors. Licensee MDPI, Basel, Switzerland. This article is an open access article distributed under the terms and conditions of the Creative Commons Attribution (CC BY) license (https:/ / creativecommons.org/licenses/by/ $4.0 /)$.
Department of Water Protection Engineering and Environmental Microbiology, Faculty of Geoengineering, University of Warmia and Mazury in Olsztyn, Prawocheńskiego 1 Str., 10-720 Olsztyn, Poland; jgroch@uwm.edu.pl (J.K.G.); rbrzoza@uwm.edu.pl (R.A.); michal.lopata@uwm.edu.pl (M.Ł.)

* Correspondence: renatat@uwm.edu.pl

\begin{abstract}
Meromictic lakes are unique aquatic ecosystems that occur extremely rarely. The phenomenon of meromixis can result from both natural and anthropogenic factors. The aim of this study was to analyse thermal and chemical stratification in a small, deep (6 ha, H max = $24.5 \mathrm{~m}$ ) lake. The evaluated lake had a typical summer thermal profile with a shallow epilimnion, a sharp thermocline, and a distinct monimolimnion layer in the hypolimnion, which was also maintained during circulation. The lake had a clinograde oxygen profile, with an oxygen deficit in the metalimnion and permanent anoxic conditions in the deeper layers, including during circulation. A redox zone was identified during summer stagnation. The monimolimnion formed a thermally isolated layer at a depth of around $15 \mathrm{~m}$, and the chemocline was situated above the monimolimnion. In the chemocline, the EC gradient ranged from 61 to $77 \mu \mathrm{S} \cdot \mathrm{cm}^{-1}$ per meter of depth in the summer and from 90 to $130 \mu \mathrm{S} \cdot \mathrm{cm}^{-1}$ per meter of depth during circulation. EC was significantly correlated with $\mathrm{Ca}^{2+}$ concentration $\left(\mathrm{r}^{2}=0.549\right)$. Chemical stratification, particularly with regard to organic matter distribution, was observed in the chemocline. The monimolimnion severely limited nutrient internal loading.
\end{abstract}

Keywords: lake; meromixis; monimolimnion; chemocline

\section{Introduction}

The intensity of water mass circulation is an indicator of the lake mixing regime and constitutes a basis for the limnological classification of lakes. Most lakes in temperate northern regions are holomictic and dimictic water bodies [1]. In these lakes, water is thoroughly mixed in autumn and spring, which produces homothermic conditions. In contrast, water circulation is highly limited in meromictic lakes [2-4]. There are relatively few meromictic lakes around the world, but their number is increasing [2,5-8]. This is the result of either anthropogenic factors (e.g., sunken opencast mining [7-10]) or the increased amount of research being conducted in this field. In Poland, less than 20 meromictic lakes have been identified to date $[9,10]$, but meromixis only naturally occurred in a few of these water bodies [11-14]. Water circulation is naturally limited in small lakes that are deeply embedded in the ground. Many of these lakes are shielded from the wind by tall trees or buildings in the immediate vicinity. Meromictic lakes are also sometimes surrounded by elevated landforms. These factors are important for small lakes with an average axis length of less $1000 \mathrm{~m}$, because the wind, which is slowed down by the obstacles above, regains its original speed at a distance equivalent to 16-times the obstacles' height [15].

In most cases, meromixis is anthropogenic and occurs in former industrial sites or flooded mines. According to the revised classification proposed by Hakala [6], meromixis also has other causes, including the inflow of fresh water into highly saline lakes, subsurface inflow of groundwater, diffuse nutrient load and turbidity currents from the catchment, and inadequate mixing due to the lake morphology and surrounding topography [3]. 
Irregular or limited water circulation produces the monimolimnion. This never mixes with the mixolimnion, which is turned over during the annual cycle [3,5]. The monimolimnion is a thermally isolated layer and can be identified based on a minor increase in the hypolimnion temperature (a fraction of $1^{\circ} \mathrm{C}$ ) in the lake's thermal profile. However, such a small temperature difference is sufficient to induce variations in water density and prevent wind mixing. Meromictic lakes are also characterised by a small increase in monimolimnion temperature [16], which remains stable throughout the year [17]. The mixolimnion and the monimolimnion are separated by the chemocline, in which the concentrations of chemical compounds, dissolved mineral salts, and organic matter [9], including microorganisms, increase rapidly [2,3,18-23]. Tartari et al. [24] provide the example of Lake Idro in Italy, where the main water layers are not separated by a chemocline. The high manganese content contributed to the formation of a stable, manganese-dominated, deep, turbid stratum enveloping the redoxcline in the upper monimolimnion.

Lake water is mixed due to differences in water density. The stability of stratified lakes is dependent on water density as a function of temperature, and it can be reinforced by the accumulation of soluble salts in the deepest layers, which increase the water density $[1,22,25,26]$. In limnological research, mineralisation is only taken into account in evaluations of water density in saline lakes. Freshwater lakes are characterised by minor differences in mineralisation, and water density can be accurately determined as a function of temperature. However, this does not change the fact that freshwater lakes are chemically stratified. According to Degermendzhy et al. [18], deep meromictic lakes have distinct gradients that divide the water column into spatially separate metaniches colonised by various species of living matter. Similar observations were made by Górniak et al. [22] and Chan et al. [27]. The stratification of water components, including organic matter, ions, and gases, is discussed in detail in the present study.

This study was conducted on an extremely interesting urban lake, which is naturally predisposed to meromixis due to a considerable Halbfass relative depth index (one of the highest values among lakes in Poland [1]), an elevated landform with a high slope, and the presence of man-made structures in the immediate vicinity. A phosphorus inactivation experiment was conducted in the lake, which increased the concentration of aluminium salts. As was shown in [9], the combination of these factors decreased the water mixing dynamics. The lake has been regularly studied by the same research unit since 1955. Lake restoration measures and changes in the lake's water mixing regime, from bradymictic to meromictic circulation, are well documented. The lake's chemical stratification was analysed in detail on three occasions during this long-term research project.

Lake meromixis is an extremely interesting phenomena, in part, because of its rarity. Water circulation in lakes is an important factor that shapes the functioning of the whole lacustrine ecosystem. Studies focused on long-term changes in the water chemical properties in meromictic lakes provide an opportunity to analyse the general trends related to changes in water circulation and chemical settings. Moreover, the fact that the studied lake underwent a particular human intervention (a restoration procedure) widens the scope as regards long-term restoration results. Therefore, the aim of this study was the long-term analysis of changes in the range of particular water strata (mixolimnion and monimolimnion). Furthermore, changes in chemical settings were studied with an emphasis on the main nutrients. Because alum was used in Starodworskie Lake restoration resulting in an increase in sulphur compounds in the lake, the concentration changes of these compounds were also analysed.

\section{Materials and Methods}

The study was conducted in Lake Starodworskie ( $\left.53^{\circ} 44^{\prime} 9^{\prime \prime} \mathrm{N}, 20^{\circ} 27^{\prime} 4^{\prime \prime} \mathrm{E}\right)$ in the city of Olsztyn (Mazury Lakeland, Poland) (Figure 1). The water mixing regime in this urban lake evolved from bradimictic circulation in the 1950s [28] to meromixis at the beginning of the 21st century. The water mixing dynamics have been decreasing steadily since the early 1990s, and the lake was classified as a permanently stratified water body in 2001 [9]. 
Lake Starodworskie is situated on the outskirts of Olsztyn. It is surrounded by high-rise buildings, tall trees, and an elevated landform with a height of $14.2-22.5 \mathrm{~m}$ and a $10-25 \%$ slope (Figure 1). The basic morphometric parameters of the evaluated lake are presented in Table 1.

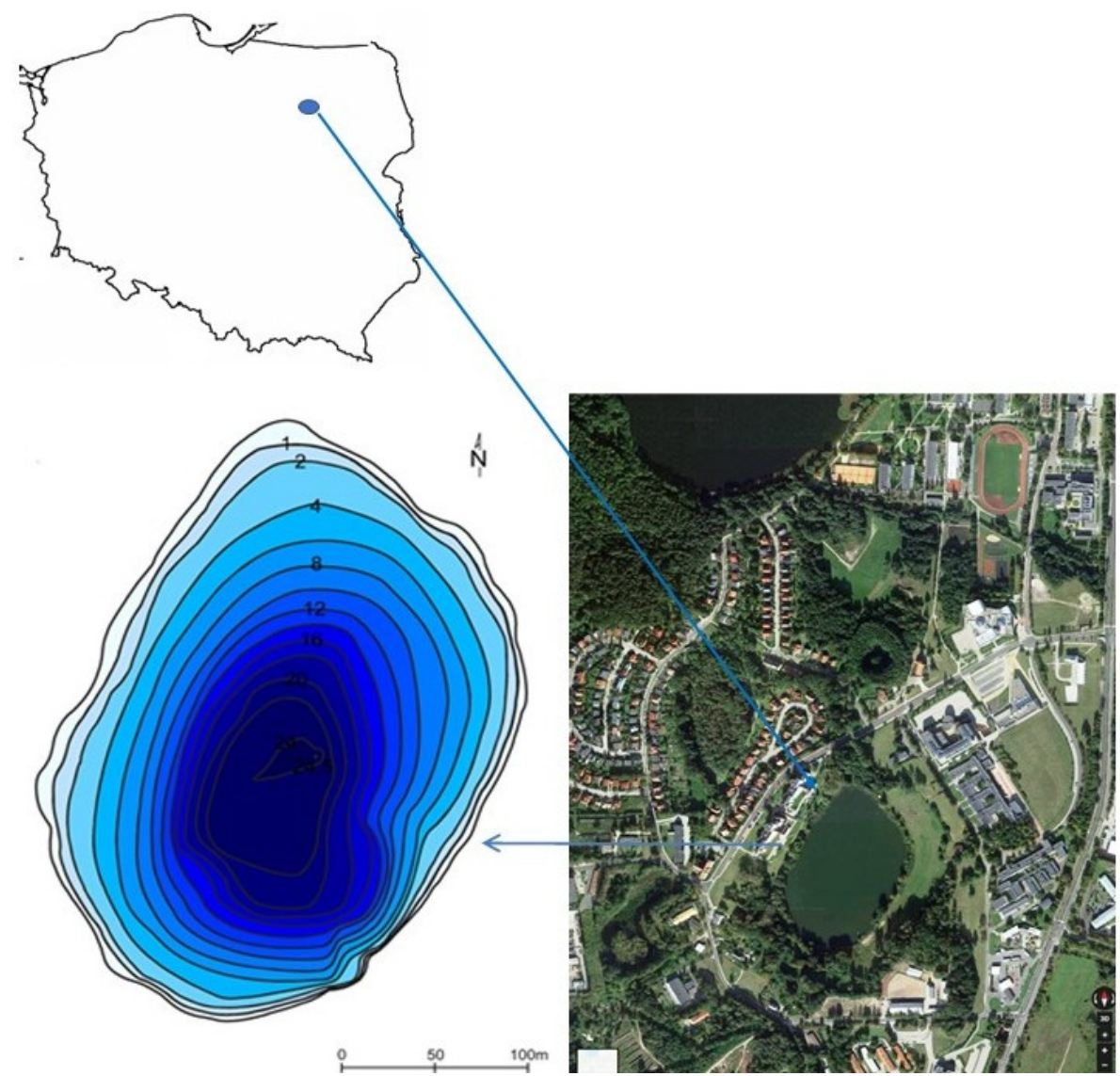

Figure 1. The location and bathymetric plan of Lake Starodworskie.

Table 1. Basic morphometric parameters of Lake Starodworskie [9].

\begin{tabular}{cc}
\hline Parameter & Value \\
\hline Elevation a.s.l. [m] & 110.85 \\
Area [ha] & 5.57 \\
Maximum depth [m] H max & 24.5 \\
Average depth [m] H aver. & 9.4 \\
Halbfass relative depth index Hr & 0.1038 \\
Indicator of depth Wg & 0.382 \\
Volume [m ${ }^{3}$ ] V & 522,014 \\
Maximum length [m] L max & 341 \\
Maximum width [m] W max & 226 \\
\hline
\end{tabular}

The lake is an experimental site of the University of Warmia and Mazury in Olsztyn. Various restoration measures have been tested in the lake [29-32]. For example, in 1994-1995, a phosphorus inactivation experiment involving aluminium sulphate was conducted in Lake Starodworskie [33], which, according to Tandyrak [9], was one of the main reasons that the water mixing regime changed to meromictic. During the experiment, a total of 15 tons of granulated coagulant were introduced into the lake's surface layer. The first dose of 5 tonnes was applied in 1994, and the second dose of 10 tonnes was introduced in 1995. The coagulant rapidly dissolved in the water and formed sedimenting flocs. The undissolved portion of the coagulant formed a layer of aluminium hydroxide on 
the surface of the bottom sediments. Aluminium hydroxide exerted two different effects: it inhibited the release of phosphorus from the bottom sediments and trapped sedimenting phosphorus [34,35].

The lake has a small catchment (less than $15 \mathrm{ha}$ ) that has been strongly modified by human activity and is characterised by various land-use types, i.e., fallow land: 70\%; mixed forest: $13.4 \%$; grassland: $5.6 \%$; built-up areas: $11 \%$. The hydrographic network comprises the lake basin and a canal that was built to evacuate excess lake water to the catchment of the Łyna River. However, surface outflows from Lake Starodworskie have not been observed in recent years.

The study was carried out between April 2004 and December 2018, and measurements were conducted five or six times a year, in all seasons. Water samples were collected in the deepest part of the lake using a 3.5-litre Ruttner sampler. Temperature (T), oxygen levels $\left(\mathrm{O}_{2}\right)$, hydrogen sulphide levels $\left(\mathrm{HS}^{-}\right)$, and conductivity (EC) were determined along the lake's vertical profile. Water samples were collected at a depth of 1, 5, 10, 15, 20, and $22 \mathrm{~m}$. In 2004, 2013, and 2016, water was also sampled at 1-meter intervals from the hypolimnion layer at a depth of 10-22 $\mathrm{m}$.

The oxygen levels (concentration and saturation) and temperature were determined with an optical oxygen probe (ProOdo YSI Inc. Yellow Springs, OH, USA); the pH and conductivity were measured with a MultiLine probe (WTW Xylem Brands Inc., US). Total phosphorus (TP), phosphate, and nitrate nitrogen (V) concentrations were determined colorimetrically with a NANOCOLOR spectrophotometer (Macherey-Nagel (GmbH\&Co. $\mathrm{KG}$, Düren, Germany). Iron, manganese, ammonia, and $\mathrm{H}_{2} \mathrm{~S}$ (as $\mathrm{HS}^{-}$) concentrations were determined with a Merck SQ118 spectrophotometer (Spectroquant Prove 100 by Merck, KGaA, Darmstadt, Germany). Sulphates were determined by weight after precipitation with $\mathrm{BaCl}_{2}$. Total nitrogen (TN) was determined in an IL 550 TOC-TN analyser (HACH Inc., Loveland, CO, USA), and organic nitrogen was calculated as the difference between $\mathrm{TN}$ and ammonium. After mineralisation with $\mathrm{H}_{2} \mathrm{SO}_{4}$ and $\mathrm{K}_{2} \mathrm{~S}_{2} \mathrm{O}_{8}$, total phosphorus (TP) and mineral phosphorus were determined with the use of ammonium molybdate and $\mathrm{SnCl}_{2}(\lambda=690 \mathrm{~nm})$. Organic phosphorus was calculated as the difference between total phosphorus and phosphate. Biochemical oxygen demand $\left(\mathrm{BOD}_{5}\right)$ was determined by dilution, and chemical oxygen demand (COD-Mn) was measured with $0.01 \mathrm{M} \mathrm{KMnO}_{4}$. In an analysis of the organic carbon fractions, particulate organic carbon (POC) and dissolved organic carbon (DOC) were separated by filtration through a membrane with a $0.45 \mu \mathrm{m}$ pore size (Sartorius). Each filter was washed with $200 \mathrm{~mL}$ of deionised water. Before the determination of organic carbon content, the sample was acidified to $\mathrm{pH} 2$ with $2 \mathrm{M} \mathrm{HCl}$, and inorganic carbon was removed by passing oxygen through the sample. Nonvolatile total organic carbon (TOC) and dissolved organic carbon (DOC) were determined in a Shimadzu TOC-5000 (Shimadzu Corp., Kyoto, Japan) and IL 550 TOC-TN analyser (HACH Inc., Loveland, CO, USA), and the content of particulate organic carbon (POC) was expressed as the difference between the organic carbon content of filtered and unfiltered samples (POC $=$ TOC-DOC). The suspension trapped between the GF/C microfibre filter and the $0.45 \mu \mathrm{m}$ membrane filter was regarded as a bacterial suspension.

The results were processed in Microsoft Excel 365 (Microsoft Corporation) $\left(\mathrm{r}^{2}\right)$ and were subjected to statistical analysis using the Statistica 13.0 software package [36]. The correlations between the selected chemical parameters in the water were determined using Spearman's nonparametric rank correlation test $(p<0.05, p<0.01)$. One-way ANOVA analysis using the Statistica software package was performed for testing significant differences between the mean values of selected hydrochemical parameters in particular years. Every sampling depth $(1,5,10,15,20$, and $22 \mathrm{~m})$ was tested separately. The significance of the differences was assessed using post-hoc Tukey test (HSD). The significance level was set as 0.05. Raw data were log transformed in order to approximate data to the normal distribution [37]. The significance of trends and their direction were analysed using the Mann-Kendall test [38]. S-test values and Kendall $\tau$ values were calculated using the 
Statistica 13.0 software package [36] and Microsoft Excel 365 (Microsoft Corporation). The significance level was set as 0.05 .

\section{Results}

An analysis of the results demonstrated that Lake Starodworskie was characterised by permanent thermal and chemical stratification. The study revealed the presence of a mixolimnion and a thermally isolated monimolimnion that does not undergo mixing and accounts for around $16 \%$ of the lake's volume (approx. 88,000 $\mathrm{m}^{3}$ ). The occurrence of thermal layers in the peak period of summer stagnation and their annual repeatability is shown in Figure 2.

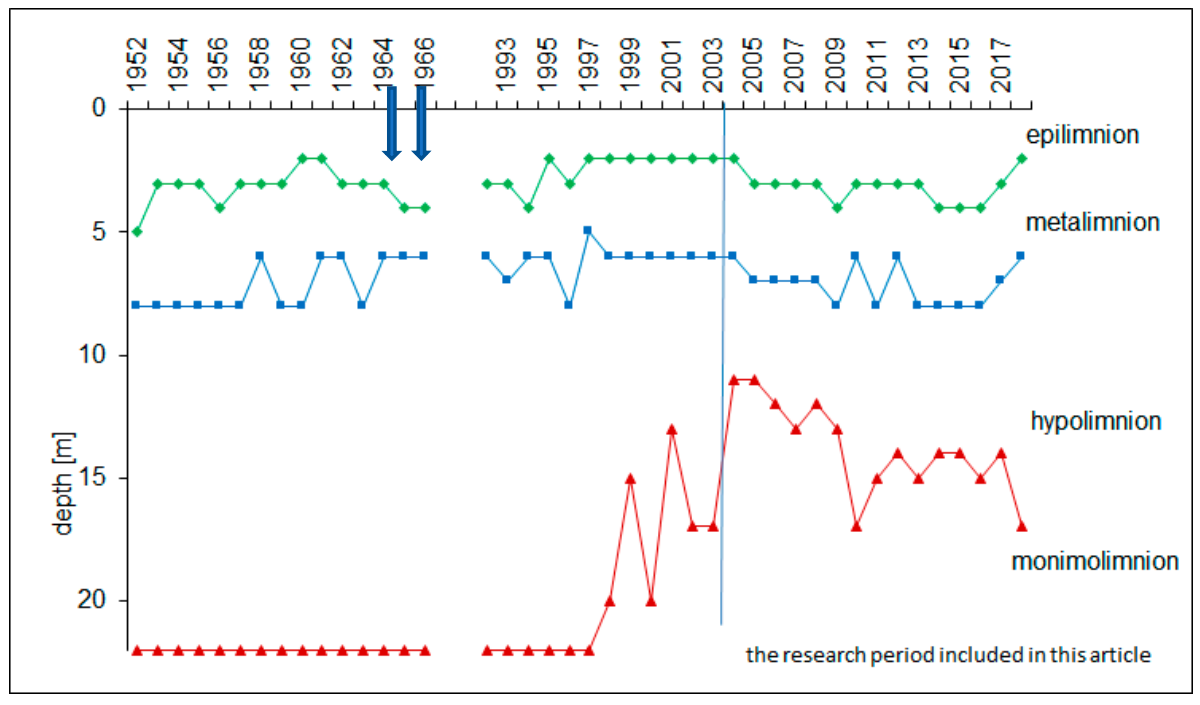

Figure 2. The range of thermal layers in the peak summer stagnation period (August) during the whole observation time. The research period included in this article is shown on the right-hand side. The blue arrows show the aluminium sulphate treatment.

The range of the monimolimnion in the research period exhibited a decreasing tendency, i.e., in the initial period, it was below $11 \mathrm{~m}$; it then decreased to $14-15 \mathrm{~m}$, and at one point reached $17 \mathrm{~m}$. This tendency is described by the following equation:

$$
\mathrm{y}=0.3071 \mathrm{x}+2.4357\left(\mathrm{r}^{2}=0.5457, \mathrm{n}=13\right) .
$$

Thermal stratification in the mixolimnion began in April and continued until late autumn. In summer, the lake had a typical thermal profile. The depth of the epilimnion increased during summer stagnation from 1 to $4 \mathrm{~m}$. The middle metalimnion layer had a depth of 7-8 m, and the deepest hypolimnion layer had an average temperature of $5.1{ }^{\circ} \mathrm{C}$. A minor increase in hypolimnion temperature was observed $\left(0.1-0.2^{\circ} \mathrm{C}\right)$ at a depth of $15-16 \mathrm{~m}$, and this thermally separated the hypolimnion from the monimolimnion. The monimolimnion was present throughout the entire study, but its thickness increased during circulation between April and July/August and decreased in November and December. In December, homothermy was not observed, even in the mixolimnion; however, the monimolimnion was clearly identifiable. During the entire study period, the monimolimnion temperature was $5.0-5.4{ }^{\circ} \mathrm{C}$, which was higher than that of the hypolimnion. The hypolimnion temperature continued to decrease from $5.2-5.4{ }^{\circ} \mathrm{C}$ in $2004-2010$ to an average of $5.1^{\circ} \mathrm{C}$ in the following years.

As a result of low water turnover during circulation, oxygen was only supplied to the shallow layers of the lake, at a depth of 9-10 m, and oxygen was depleted in the mixolimnion during the entire study period (Figure 3). During summer stagnation, the epilimnion was saturated with oxygen $\left(>100 \% \mathrm{O}_{2}\right)$, and rapid oxygen loss and oxygen deficiency were noted in the metalimnion. Oxygen was replaced by hydrogen sulphide. 
In the winter, $\mathrm{H}_{2} \mathrm{~S}$ appeared immediately after oxygen depletion, while in the summer, a redox layer was formed, in which both gases were absent. Thermal stratification was reinforced by chemical stratification. The chemocline was identified based on the distribution of electrolytic conductivity values in the vertical profile. The chemocline was located in the hypolimnion at a depth of 12-15 $\mathrm{m}$, somewhat above a layer characterised by a minor change in temperature, which cut off the monimolimnion (Figure 3). This layer accounted for $8 \%$ of the water volume in the lake (about $46,785 \mathrm{~m}^{3}$ ). At the peak of the summer stagnation period, a rapid increase in conductivity towards the lake bottom was noted on several occasions, and this was accompanied by minor changes in the temperature in the vertical profile. Conductivity increased by $61-77 \mu \mathrm{S} \cdot \mathrm{cm}^{-1}$ at a depth of $12-15 \mathrm{~m}$. In December, when the chemocline formed a distinct layer, its conductivity increased by $90-130 \mu \mathrm{S} \cdot \mathrm{cm}^{-1}$ in the vertical profile.

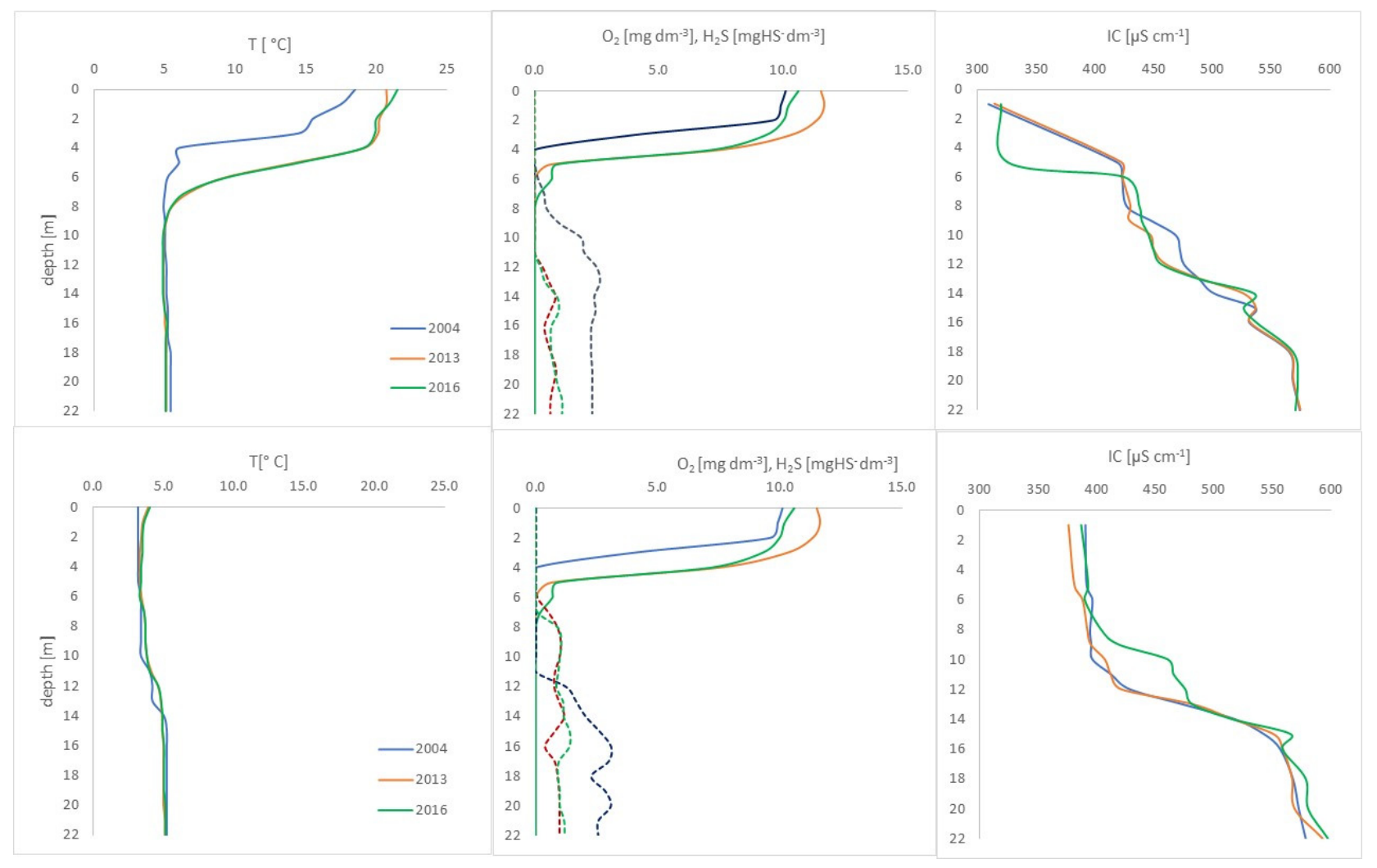

Figure 3. Examples of the vertical thermal profile, the oxygen and hydrogen sulphide (dot line) concentrations, and conductivity in Lake Starodworskie in August (upper panel) and December (lower panel).

Water $\mathrm{pH}$ decreased (from slightly alkaline, with an average $\mathrm{pH}$ of $8.50 \pm 0.35$ during the summer period, to $7.84 \pm 0.45$ during the rest of the year) within the neutral range in the chemocline, whereas the concentrations of soluble salts, calcium in particular, increased significantly. The concentrations of magnesium, manganese, phosphates, and ammonia nitrogen also increased in the vertical profile, but the observed increase was not significant. However, a significant correlation was observed between calcium concentration and conductivity $\left(\mathrm{r}^{2}=0.5488 ; \mathrm{n}=15 ; p<0.05\right)$ (Figure 4$)$. Chloride levels remained fairly stable, but a decrease in sulphate concentrations and an increase in hydrogen sulphide levels were observed in the initial period of the study. From 2008, the hydrogen sulphide levels stabilised; however, the sulphate concentration returned to values noted before lake restoration (6.68-8.77 $\mathrm{mg} \mathrm{dm}^{-3}$ ) (Figure 5). At a depth of $15 \mathrm{~m}$, total ion concentrations increased by an average of $14.21 \mathrm{mg} \mathrm{dm}^{-3}$, as compared to values from a depth of $12 \mathrm{~m}$. 

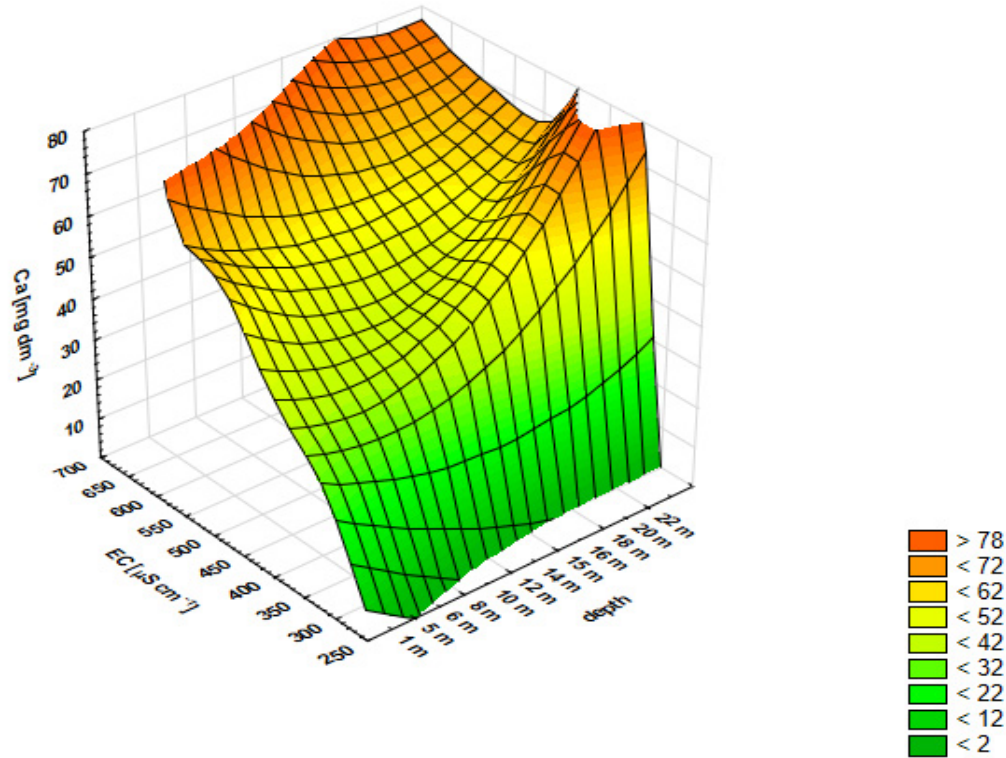

Figure 4. The vertical profile of calcium concentration in Lake Starodworskie according to conductivity. The legend shows the calcium concentration.

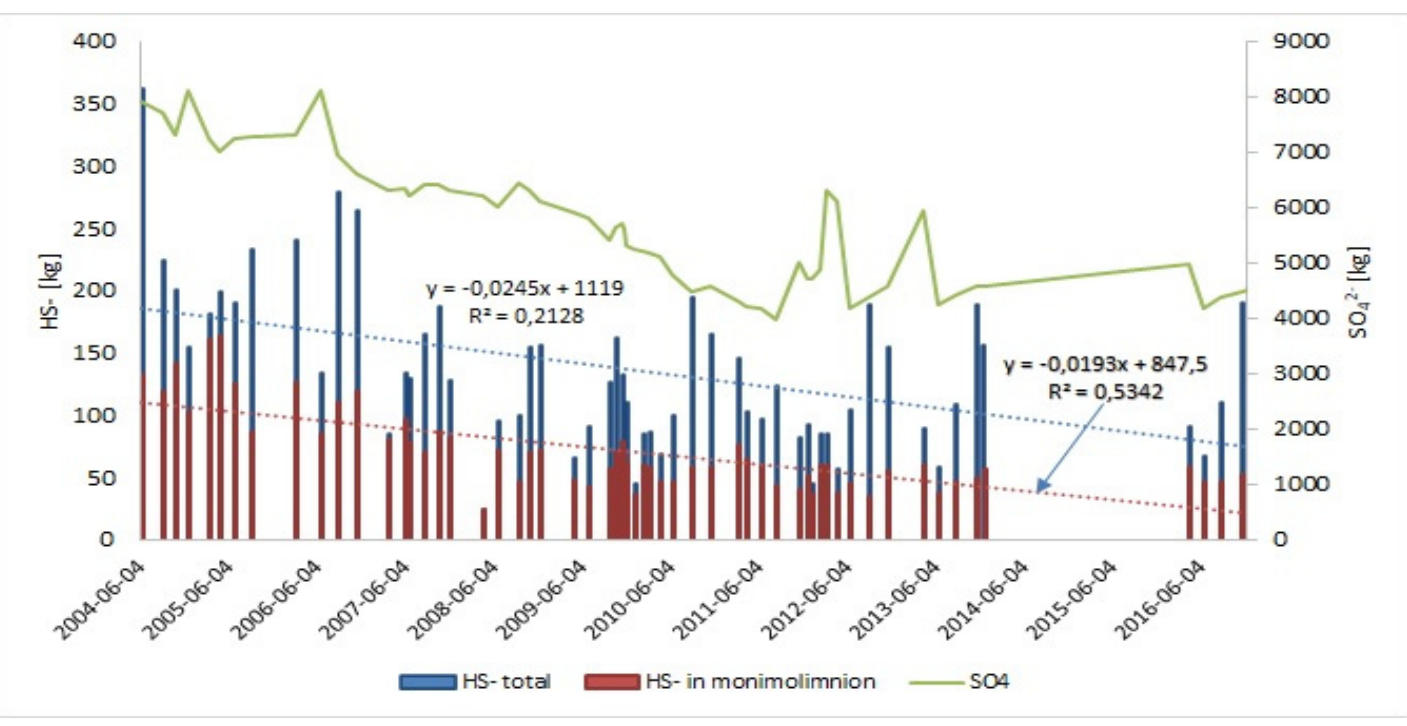

Figure 5. Total amount of sulphate and hydrogen sulphide in Lake Starodworskie water.

The trend analysis using the Mann-Kendall test demonstrated that change trends for the chemical parameters analysed at selected water depths were mostly significant $(p<0.05)$. For ammonia, calcium, and the sulphur compounds analysed, negative statistical values confirmed a negative trend. Moreover, positive Mann-Kendall statistical results for phosphates, iron, and manganese revealed that the concentration of those parameters was increasing with time. The results are presented in Table 2.

The organic matter content increased in the chemocline (Figure 6). In the upper layer or directly above the upper layer of the chemocline (at a depth of $10 \mathrm{~m}$ and, most frequently, at $12 \mathrm{~m}$ ), the organic matter concentration in the suspension (POC) increased, and it was characterised by a high content (40-61\%) of bacterial suspension. Dissolved organic matter $(2.9 \leq$ DOC $/ \mathrm{POC} \leq 9.3)$ was mainly accumulated in the lower part of the chemocline at a depth of $14 \mathrm{~m}$, and it was transferred from the chemocline to the monimolimnion. Similar to the chemocline, the monimolimnion contained mostly dissolved ( $2.6 \leq \mathrm{DOC} / \mathrm{POC} \leq 6.6)$, easily degradable organic matter $\left(0.9 \leq \mathrm{BOD}_{5} / \mathrm{COD}-\mathrm{Mn} \leq 3.2\right)$. During the entire study period, $\mathrm{BOD}_{5}$ remained fairly stable, in 
a range of 1350-2107 $\mathrm{kg} \mathrm{O}_{2}$ (Table 2). Organic matter content was correlated with the hydrogen sulphide concentration, which was accumulated in the monimolimnion $\left(r^{2}=0.3154 ; n=78\right)$.

Table 2. Results of the Mann-Kendall analysis. Significant results $(p<0.05)$ are presented. Other results are indicated as NS (nonsignificant).

\begin{tabular}{|c|c|c|c|}
\hline Hydrochemical Parameter & Water Depth & S Value & $\tau$ Value \\
\hline \multirow{6}{*}{$\mathrm{N}-\mathrm{NH}_{4}$} & $1 \mathrm{~m}$ & NS & NS \\
\hline & $5 \mathrm{~m}$ & -603.42 & -0.25721 \\
\hline & $10 \mathrm{~m}$ & NS & NS \\
\hline & $15 \mathrm{~m}$ & -878.46 & -0.37445 \\
\hline & $20 \mathrm{~m}$ & -1120.75 & -0.47773 \\
\hline & $22 \mathrm{~m}$ & -1062.10 & -0.45273 \\
\hline \multirow{6}{*}{$\mathrm{P}-\mathrm{PO}_{4}$} & $1 \mathrm{~m}$ & NS & NS \\
\hline & $5 \mathrm{~m}$ & NS & NS \\
\hline & $10 \mathrm{~m}$ & 803.93 & 0.352911 \\
\hline & $15 \mathrm{~m}$ & 1045.53 & 0.458967 \\
\hline & $20 \mathrm{~m}$ & 1010.86 & 0.443749 \\
\hline & $22 \mathrm{~m}$ & 1097.91 & 0.481961 \\
\hline \multirow{6}{*}{$\mathrm{Fe}$} & $1 \mathrm{~m}$ & NS & NS \\
\hline & $5 \mathrm{~m}$ & NS & NS \\
\hline & $10 \mathrm{~m}$ & NS & NS \\
\hline & $15 \mathrm{~m}$ & 615.43 & 0.278349 \\
\hline & $20 \mathrm{~m}$ & 463.96 & 0.209842 \\
\hline & $22 \mathrm{~m}$ & 720.74 & 0.325978 \\
\hline \multirow{6}{*}{ Mn } & $1 \mathrm{~m}$ & NS & NS \\
\hline & $5 \mathrm{~m}$ & 612.48 & 0.285537 \\
\hline & $10 \mathrm{~m}$ & 400.76 & 0.186835 \\
\hline & $15 \mathrm{~m}$ & NS & NS \\
\hline & $20 \mathrm{~m}$ & 436.32 & 0.203114 \\
\hline & $22 \mathrm{~m}$ & 490.12 & 0.228496 \\
\hline \multirow{6}{*}{$\mathrm{Ca}$} & $1 \mathrm{~m}$ & NS & NS \\
\hline & $5 \mathrm{~m}$ & -729.91 & -0.35092 \\
\hline & $10 \mathrm{~m}$ & NS & NS \\
\hline & $15 \mathrm{~m}$ & -879.43 & -0.4228 \\
\hline & $20 \mathrm{~m}$ & NS & NS \\
\hline & $22 \mathrm{~m}$ & NS & NS \\
\hline \multirow{6}{*}{$\mathrm{H}_{2} \mathrm{~S}$} & $1 \mathrm{~m}$ & NS & NS \\
\hline & $5 \mathrm{~m}$ & NS & NS \\
\hline & $10 \mathrm{~m}$ & NS & NS \\
\hline & $15 \mathrm{~m}$ & -779.97 & -0.42621 \\
\hline & $20 \mathrm{~m}$ & -915.62 & -0.50034 \\
\hline & $22 \mathrm{~m}$ & -824.18 & -0.45037 \\
\hline \multirow{6}{*}{$\mathrm{SO}_{4}$} & $1 \mathrm{~m}$ & -451.75 & -0.52468 \\
\hline & $5 \mathrm{~m}$ & -589.31 & -0.68445 \\
\hline & $10 \mathrm{~m}$ & -467.86 & -0.54339 \\
\hline & $15 \mathrm{~m}$ & -395.81 & -0.45971 \\
\hline & $20 \mathrm{~m}$ & -388.05 & -0.4507 \\
\hline & $22 \mathrm{~m}$ & -412.701 & -0.47933 \\
\hline
\end{tabular}




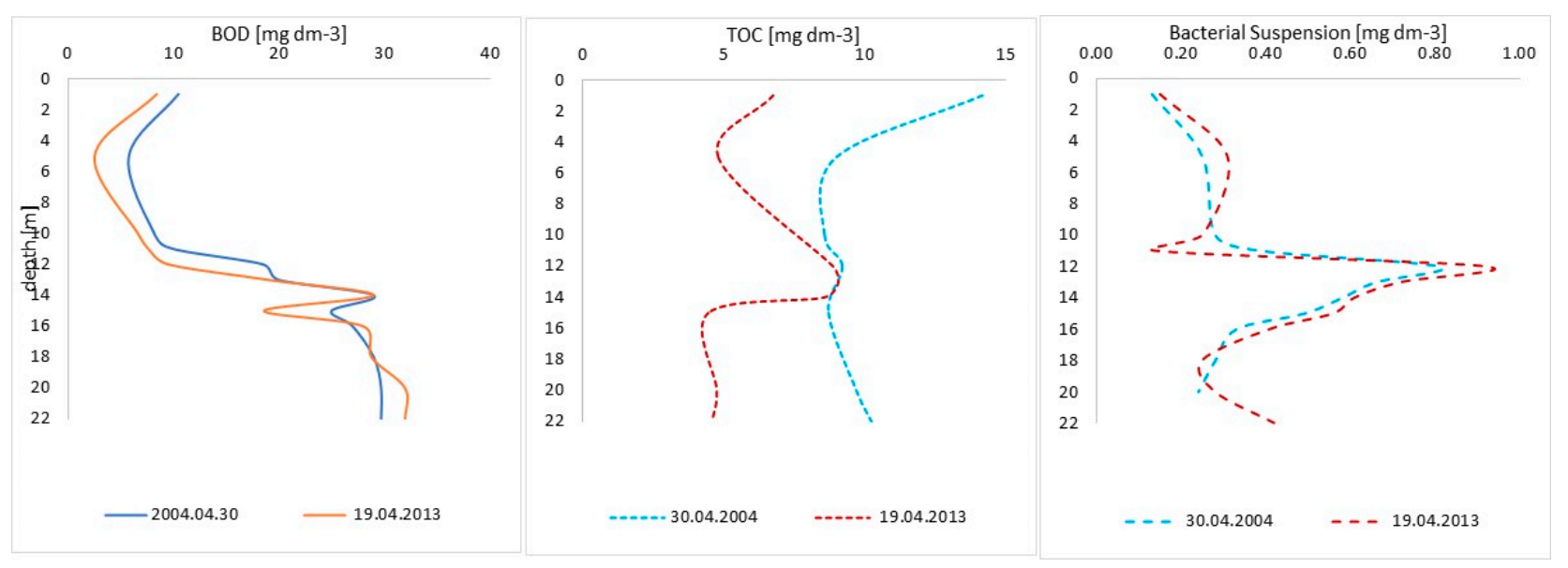

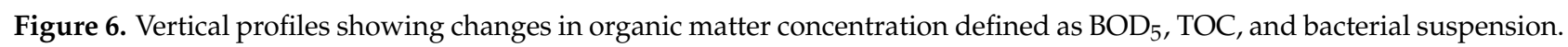

The monimolimnion accumulated the majority of gases produced in the lake. At the beginning of the study period, this layer accumulated $85-90 \%$ of total hydrogen sulphide (123-327.5 $\mathrm{kg} \mathrm{HS}^{-2}$ ) (Figure 5) and approximately $80 \%$ of total carbon dioxide (1888.7-1916.6 $\mathrm{kg} \mathrm{CO}_{2}$ ). In 2016, the aforementioned loads decreased to $67.2-189.3 \mathrm{~kg}$ HS $^{-}(27-69.9 \%)$ and $1242.2-1314 \mathrm{~kg} \mathrm{CO}_{2}(30.5-40 \%)$, respectively. The predominant ions were calcium (52.1 $\mathrm{mg} \mathrm{dm}^{-3}$ on average), magnesium ( $7.37 \mathrm{mg} \mathrm{dm}^{-3}$ on average), and sulphates (9.04 $\mathrm{mg} \mathrm{dm}^{-3}$ on average). During the entire study period, nearly half the total ammonia nitrogen (max. $671.7 \mathrm{~kg}$ ) and total phosphorus $(98.2 \mathrm{~kg}$ ) were accumulated in the monimolimnion, whereas the phosphate content exceeded 60\% (68.1 kg) (Table 3).

Table 3. The range of changes in the organic matter and biogenic element contents in the monimolimnion of Lake Starodworskie (Tandyrak 2017 [9], with modifications).

\begin{tabular}{ccc}
\hline Component & Content (kg) & $\begin{array}{c}\text { \% of Total Amount in the } \\
\text { Whole Lake }\end{array}$ \\
\hline BOD $_{5}$ & $1350-2107$ & $33-42$ \\
\hline COD-Mn & $581-830.9$ & $9-12.5$ \\
\hline TOC & $421.9-509.1$ & $7-9$ \\
\hline POC & $64.5-119.3$ & $5-9$ \\
\hline DOC & $222.9-423.6$ & $6-10$ \\
\hline Bacterial suspension & $3.9-37.5$ & $2-24$ \\
\hline PO $_{4}$ & $22.4-68.1$ & $22-63$ \\
\hline $\mathrm{TP}^{\mathrm{N}-\mathrm{NH}_{4}}$ & $40.7-98.2$ & $15-50$ \\
\hline $\mathrm{TN}$ & $260.4-671.7$ & $18-50$ \\
\hline
\end{tabular}

The analysed chemical compounds $(\mathrm{n}=78)$ demonstrated highly significant correlations (Table 4). The Spearman's rank correlation coefficient values were determined as being 0.498 for $\mathrm{H}_{2} \mathrm{~S}$ and $\mathrm{SO}_{4}{ }^{-2}, 0.637$ for $\mathrm{H}_{2} \mathrm{~S}$ and $\mathrm{BOD}_{5}$, and 0.518 for $\mathrm{SO}_{4}{ }^{-2}$ and $\mathrm{BOD}_{5}$. The other coefficients are listed in Table 4 . In the vertical profile, dissolved salt concentrations decreased in the deepest layer (in particular, $\mathrm{N}^{-\mathrm{NH}_{4}}$ and $\mathrm{Mn}$ ); however, they were significantly higher throughout the monimolimnion than in the mixolimnion. 
Table 4. Spearman's rank correlation coefficients for selected chemical parameters of the monimolimnion in Lake Starodworskie $\left({ }^{*}\right.$ significant at $p<0.05$; ${ }^{*}$ significant at $p<0.01$ ).

\begin{tabular}{ccccccc}
\hline & EC & Ca & Mg & Fe & N-NH & PO $_{4}$ \\
\hline Depth & $0.925^{*}$ & $0.746^{* *}$ & -0.089 & 0.299 & $0.768^{* *}$ & $0.682^{* *}$ \\
\hline EC & 1.000 & $0.805^{* *}$ & -0.082 & 0.291 & $0.836^{* *}$ & $0.768^{* *}$ \\
\hline $\mathrm{Ca}$ & & 1.000 & $-0.336^{*}$ & $0.349^{*}$ & $0.653^{* *}$ & $0.614^{* *}$ \\
\hline $\mathrm{Mg}$ & & 1.000 & 0.077 & 0.099 & -0.023 \\
\hline $\mathrm{Fe}$ & & & 1.000 & $0.358^{*}$ & 0.266 \\
\hline $\mathrm{Mn}$ & & & & -0.184 & -0.155 \\
\hline $\mathrm{N}-\mathrm{NH}_{4}$ & & & & & 1.000 & $0.646^{*}$ \\
\hline $\mathrm{PO}_{4}$ & & & & & & 1.000 \\
\hline
\end{tabular}

The one-way ANOVA analysis results revealed that significant differences between the mean values of selected parameters were detected in the deeper parts of the lake, i.e., on the border between the mixolimnion and monimolimnion, and in the monimolimnion itself. This appears to confirm the supposition that deeper parts of the meromictic lake, including the monimolimnion, are subjected to certain active processes, which can lead to significant concentration changes; however, this process takes a long time, which is demonstrated by the significant differences between the first (2004 and 2005, and sometimes 2006 and 2007) and last years of research (mainly beyond 2011). Both sulphur compound concentrations $\left(\mathrm{SO}_{4}\right.$ and $\mathrm{H}_{2} \mathrm{~S}$ ) decreased with time. This occurred simultaneously with noticeable increases in Fe and Mn concentrations. The negative trend noted for the sulphur compounds was confirmed using Mann-Kendall analysis (Table 2). Changes in phosphate concentrations were less clear. Among the analysed hydrochemical parameters, the ammonia concentration did not exhibit significant concentration changes (except in water at a depth of $5 \mathrm{~m}$ and $20 \mathrm{~m}$ ) (Table 5). However, the results of the Mann-Kendall test (Table 2) showed a negative trend in ammonia concentration changes.

Table 5. Results of the one-way ANOVA analysis (effect $\mathrm{df}=12$, error $\mathrm{df}=52$ ) for the selected hydrochemical parameters of Starodworskie Lake water. Raw data were log transformed. Results above a significance level of 0.05 are marked as nonsignificant (NS).

\begin{tabular}{|c|c|c|c|c|}
\hline $\begin{array}{l}\text { Hydrochemical } \\
\text { Parameter }\end{array}$ & Water Depth & F Value & $p$ Value & Significant Differences between Years \\
\hline \multirow{6}{*}{$\mathrm{N}-\mathrm{NH}_{4}$} & $1 \mathrm{~m}$ & NS & NS & - \\
\hline & $5 \mathrm{~m}$ & 2.62 & 0.0074 & between 2005 and 2007 \\
\hline & $10 \mathrm{~m}$ & NS & NS & - \\
\hline & $15 \mathrm{~m}$ & NS & NS & - \\
\hline & $20 \mathrm{~m}$ & 2.06 & 0.035 & between 2006 and 2014 \\
\hline & $22 \mathrm{~m}$ & NS & NS & - \\
\hline \multirow{6}{*}{$\mathrm{P}-\mathrm{PO}_{4}$} & $1 \mathrm{~m}$ & NS & NS & - \\
\hline & $5 \mathrm{~m}$ & NS & NS & - \\
\hline & $10 \mathrm{~m}$ & 3.24 & 0.0014 & between 2005 and 2016 \\
\hline & $15 \mathrm{~m}$ & 6.58 & 0.000 & between 2005 and 2006, 2009-16 \\
\hline & $20 \mathrm{~m}$ & NS & NS & - \\
\hline & $22 \mathrm{~m}$ & 7.39 & 0.000 & $\begin{array}{l}\text { between } 2004 \text { and 2011-12,2015-16 } \\
\text { between } 2005 \text { and 2011, 2013 } \\
\text { between } 2006 \text { and 2011, 2013 } \\
\text { between } 2007 \text { and 2010-13, 2015-16 } \\
\text { between } 2008 \text { and 2010-13, 2015-16 }\end{array}$ \\
\hline
\end{tabular}


Table 5. Cont.

\begin{tabular}{|c|c|c|c|c|}
\hline $\begin{array}{l}\text { Hydrochemical } \\
\text { Parameter }\end{array}$ & Water Depth & F Value & $p$ Value & Significant Differences between Years \\
\hline \multirow{6}{*}{$\mathrm{Fe}$} & $1 \mathrm{~m}$ & NS & NS & - \\
\hline & $5 \mathrm{~m}$ & NS & NS & - \\
\hline & $10 \mathrm{~m}$ & 3.24 & 0.0015 & $\begin{array}{l}\text { between } 2011 \text { and 2004,2007-08, 2010, 2012, } \\
\qquad 2014-16\end{array}$ \\
\hline & $15 \mathrm{~m}$ & 4.13 & 0.0001 & $\begin{array}{l}\text { between } 2004 \text { and 2011, 2013, } 2016 \\
\text { between } 2007 \text { and 2009, 2013, } 2016\end{array}$ \\
\hline & $20 \mathrm{~m}$ & 2.99 & 0.0029 & between 2004 and 2009, 2011, 2013, 2016 \\
\hline & $22 \mathrm{~m}$ & 7.27 & 0.0000 & $\begin{array}{l}\text { between } 2004 \text { and 2008-16 } \\
\text { between } 2006 \text { and 2011, 2013 } \\
\text { between } 2007 \text { and 2009, 2011, } 2013\end{array}$ \\
\hline \multirow{6}{*}{ Mn } & $1 \mathrm{~m}$ & NS & NS & - \\
\hline & $5 \mathrm{~m}$ & NS & NS & - \\
\hline & $10 \mathrm{~m}$ & 5.17 & 0.0000 & $\begin{array}{c}\text { between } 2004 \text { and 2010, 2012-13 } \\
\text { between } 2009 \text { and 2010, 2012-13 } \\
\text { between } 2011 \text { and 2012 } \\
\text { between } 2012 \text { and } 2014\end{array}$ \\
\hline & $15 \mathrm{~m}$ & 2.99 & 0.0030 & between 2004 and 2007-09 \\
\hline & $20 \mathrm{~m}$ & 5.50 & 0.0000 & $\begin{array}{l}\text { between } 2004 \text { and 2007-16 } \\
\text { between } 2005 \text { and 2009, 2011, } 2014\end{array}$ \\
\hline & $22 \mathrm{~m}$ & 5.09 & 0.0000 & $\begin{array}{c}\text { between } 2004 \text { and 2007-14, } 2016 \\
\text { between } 2005 \text { and } 2009\end{array}$ \\
\hline \multirow{6}{*}{$\mathrm{Ca}$} & $1 \mathrm{~m}$ & NS & NS & - \\
\hline & $5 \mathrm{~m}$ & NS & NS & - \\
\hline & $10 \mathrm{~m}$ & NS & NS & - \\
\hline & $15 \mathrm{~m}$ & NS & NS & - \\
\hline & $20 \mathrm{~m}$ & 4.77 & 0.0000 & $\begin{array}{l}\text { between } 2004 \text { and 2008-09 } \\
\text { between } 2005 \text { and 2008-09 } \\
\text { between } 2006 \text { and 2008 } \\
\text { between } 2008 \text { and 2014-15 }\end{array}$ \\
\hline & $22 \mathrm{~m}$ & 5.78 & 0.0000 & $\begin{array}{l}\text { between } 2004 \text { and } 2007-10,2012-13 \\
\text { between } 2005 \text { and 2007-2010 } \\
\text { between } 2006 \text { and 2008-09 }\end{array}$ \\
\hline \multirow{6}{*}{$\mathrm{H}_{2} \mathrm{~S}$} & $1 \mathrm{~m}$ & NS & NS & - \\
\hline & $5 \mathrm{~m}$ & NS & NS & - \\
\hline & $10 \mathrm{~m}$ & NS & NS & - \\
\hline & $15 \mathrm{~m}$ & 6.81 & 0.0000 & $\begin{array}{l}\text { between } 2004 \text { and 2008, 2010-16 } \\
\text { between } 2005 \text { and 2008, 2010-16 } \\
\text { between } 2006 \text { and 2008, 2011 }\end{array}$ \\
\hline & $20 \mathrm{~m}$ & 12.55 & 0.0000 & $\begin{array}{l}\text { between } 2004 \text { and 2007-16 } \\
\text { between } 2005 \text { and 2007-16 } \\
\text { between } 2006 \text { and 2008-10, 2012-16 }\end{array}$ \\
\hline & $22 \mathrm{~m}$ & 7.95 & 0.0000 & $\begin{array}{l}\text { between } 2004 \text { and 2008-16 } \\
\text { between } 2005 \text { and 2009-13 }\end{array}$ \\
\hline
\end{tabular}


Table 5. Cont.

\begin{tabular}{|c|c|c|c|c|}
\hline $\begin{array}{l}\text { Hydrochemical } \\
\text { Parameter }\end{array}$ & Water Depth & F Value & $p$ Value & Significant Differences between Years \\
\hline \multirow{6}{*}{$\mathrm{SO}_{4}$} & $1 \mathrm{~m}$ & 11.04 & 0.0000 & between 2011 and 2004-07, 2012-16 \\
\hline & $5 \mathrm{~m}$ & 12.90 & 0.0000 & $\begin{array}{l}\text { between } 2004 \text { and 2007, 2010-16 } \\
\text { between } 2005 \text { and 2010-16 } \\
\text { between } 2006 \text { and 2010-16 } \\
\text { between } 2007 \text { and } 2016\end{array}$ \\
\hline & $10 \mathrm{~m}$ & 6.62 & 0.0000 & $\begin{array}{l}\text { between } 2004 \text { and 2010, 2013-16 } \\
\text { between } 2005 \text { and 2010, 2013 } \\
\text { between } 2006 \text { and } 2013 \\
\text { between } 2007 \text { and } 2013\end{array}$ \\
\hline & $15 \mathrm{~m}$ & 5.03 & 0.0003 & $\begin{array}{c}\text { between } 2004 \text { and 2010, 2013-16 } \\
\text { between } 2007 \text { and 2013-16 }\end{array}$ \\
\hline & $20 \mathrm{~m}$ & 8.20 & 0.0000 & $\begin{array}{l}\text { between } 2004 \text { and } 2010-11,2013-16 \\
\text { between } 2006 \text { and } 2010-11,2013-16 \\
\text { between } 2007 \text { and } 2010-11,2013-16\end{array}$ \\
\hline & $22 \mathrm{~m}$ & 6.66 & 0.0000 & $\begin{array}{l}\text { between } 2004 \text { and 2010, 2013-16 } \\
\text { between } 2006 \text { and 2010, 2013-16 } \\
\text { between } 2007 \text { and 2010, 2013-16 }\end{array}$ \\
\hline
\end{tabular}

\section{Discussion}

The present study is a part of a long-term research project that has been conducted in Lake Starodworskie since 1955, i.e., for more than 60 years. At the beginning of the research period, the lake was a bradymictic water body, and its mictic regime has continued to evolve throughout the years. The changes in the lake's water mixing regime were analysed by Tandyrak [9], who demonstrated that meromixis only occurred several years after phosphorus had been inactivated with the use of aluminium sulphate. The one-way ANOVA analysis results confirmed that changes in phosphate concentrations were less marked, which could result from previous phosphorus inactivation $[9,35]$. The performed treatment did not change the ammonia content. This may be due to continuous biological transformations of this nitrogen form in the mixolimnion and monimolimnion. Other authors $[8,39]$ also reported no significant changes in the nitrogen compounds in lakes restored via the phosphorus inactivation method. Augustyniak et al. [35] reported a similar ammonia level in the profundal zone of Starodworskie Lake in 2016, as compared to the year before phosphorus inactivation (1994). Lake Starodworskie was still a bradimictic water body 6 years after the aforementioned treatment, but meromictic episodes were noted with increasing frequency. The coagulant introduced into the lake's surface was partially dissolved and hydrolysed to produce aluminium sulphate flocs, which were sedimented at the bottom; however, certain amounts of aluminium sulphate were also directly deposited at the bottom of the lake. The deposited coagulant slowly dissolved, and it modified the sorptive complex of the bottom sediments $[34,35]$ and enriched deep layers with principally $\mathrm{SO}_{4}{ }^{2-}$ ions. The aluminium sulphate concentration increased from less than 20 to more than $40 \mathrm{mg} \mathrm{dm}^{-3}$ in the hypolimnion. The coagulant not only changed the water density, in the hypolimnion in particular, but also initiated a series of chemical and microbiological processes that shaped the lake's monimolimnion.

Meromictic circulation increases thermal stability in a water body [39-44]. According to Ambrosetti and Barbanti [41], Walker [43], and Wuest et al. [44], chemical stability increases salinity (such as TDS (total dissolved salts)). However, when the concentrations of individual salts are unknown, the load of different ions is difficult to determine, because salts differ in electrolytic conductivity [45]. For this reason, the distribution of the major ions and nonionic compounds was evaluated in the vertical profile. It was found that the stratification of $\mathrm{Ca}^{2+}$ ions that were most abundant in Lake Starodworskie had the 
greatest influence on chemical stratification. These findings are not fully consistent with the observations made by Lange [45], because other ions that occurred at high concentrations $\left(\mathrm{Mg}^{2+}, \mathrm{Cl}^{-}, \mathrm{SO}^{2-}\right)$ were not stratified or correlated with conductivity. This can probably be attributed to the high rate of change in ion concentrations [46]. The content of $\mathrm{Mn}^{2+}, \mathrm{NH}_{4}{ }^{+}$, and $\mathrm{PO}_{4}{ }^{3-}$ ions was also highly correlated with conductivity $\left(\mathrm{r}^{2}=0.836\right.$ and 0.768 , respectively).

In the vertical thermal profile, the monimolimnion was identified based on a minor temperature increase in the hypolimnion [16] (in that particular case, at 15-16 m), which induced changes in the water density. Lange [45] noted that the density of freshwater bodies characterised by minor differences in mineralisation can be reliably determined as a function of temperature. Other authors also observed that chemical stability has a small influence on a lake's overall stability and water dynamics $[40,42,43]$. An increase in mineralisation of $10 \mathrm{mg} \cdot \mathrm{dm}^{-3}$ induces similar changes in density as those caused by an increase in temperature of $4-5{ }^{\circ} \mathrm{C}$ or an increase in pressure of $0.1 \mathrm{~atm}$ [45]. The chemocline was formed somewhat higher (12-15 m), and it was characterised by both an increase in electrolytic conductivity in the hydrochemical profile, which evidenced growing mineral loads, and an increase in $\mathrm{BOD}_{5}, \mathrm{TOC}$, and $\mathrm{POC}$ with bacterial suspensions. In consequence, the monimolimnion was both thermally and chemically isolated from the remaining layers of the lake. The same was observed by Degermendzhy et al. [18]. The analysis of the vertical distribution of these components showed a clear reduction in concentrations below the layer that separated the chemocline and the monimolimnion, and then a systematic increase towards the bottom. This suggests that, at this point, there was slower sedimentation and a slower transfer of water components to the monimolimnion. The permanent density stratification within the monimolimnion limits the vertical transport of both water and solutes [47].

The concepts of thermal stability and meromictic (chemical) stability were introduced by Walker [43]. Chemical stability is only a minor contributor to a lake's overall stability, but it is the key inhibitor of holomixis. Wuest et al. [44] defined total quantitative stability as a function of temperature and the concentrations of dissolved salts and nonionic substances. These parameters can be regarded as integrated values in the overall water mass, and they can be compared across lakes [41]. They can also be analysed in the vertical profile to determine the hydrodynamic mechanisms that take place at every depth, both during summer stratification and circulation.

The chemocline is usually the outcome of differences in oxygen concentration, where microbial activity can lead to the permanent loss of organic matter produced in the surface layer $[25,48]$. An increase in water density due to the dissolution of salts (as confirmed by conductivity values) slows organic matter sedimentation. In Lake Starodworskie, the aforementioned mechanism was confirmed by an increase in the concentration of POC and bacterial suspension in the upper layer of the chemocline and directly above it. The bacterial biocenosis that is formed in the aforementioned area under anoxic conditions, i.e., high accumulation of readily available organic matter and a relatively low temperature, is characterised by abundance, a high biomass, and large cell sizes [9,22,26]. A detailed analysis of the vertical profile in Lake Starodworskie revealed the lowest standard deviation values for seasonal changes in TOC concentration at a depth of $12 \mathrm{~m}( \pm 0.705)$ and POC concentration $( \pm 0.165)$. The aforementioned results indicate stable conditions and a slow rate of sedimentation in the chemocline.

In a meromictic lake, organic matter is transported through the chemocline to the monimolimnion, and theoretically, it is unable to return to the oxygen-rich layer. According to Boehrer and Schultze [2], prolonged autumn circulation can erode the monimolimnion. This process is assisted by gas convection [3]. This was observed in Lake Starodworskie in the last years of the study, when autumn circulation was prolonged until December, water mixing reached the chemocline, and chemocline components were distributed to other layers. As demonstrated by this study and others $[14,22,23,30]$, the monimolimnion is an isolated layer that is abundant in biogenic elements. This layer probably traps biogenic 
elements which, similar to the elements accumulated in bottom sediments, can also be released (to a lesser extent) under anoxic conditions and distributed during circulation. The study of Rogozin et al. [49] in Lake Shira in Siberia and by Czeczuga [50] in Lake Wadołek in Poland suggest that deep water mixing can increase eutrophication due to a supply of biogenic elements, which leads to a significant increase in algal biomass during the growing season.

The monimolimnion does not exchange gases with the atmosphere, and it is a thermally isolated layer between groundwater and the hypolimnion [2]. The monimolimnion is also exposed to high hydrostatic pressure, which is why the concentration of gases, such as carbon dioxide, methane [51], and hydrogen sulphide [52], are much higher than in the mixolimnion. The presence of hydrogen sulphide is largely dependent on water $\mathrm{pH}$, and $\mathrm{pH}$ is determined by the amount of $\mathrm{CO}_{2}$ released by decomposing organic matter [53]. In Lake Starodworskie, the monimolimnion had a slightly acidic to neutral $\mathrm{pH}$, and hydrogen sulphide occurred mainly as dissolved gas [54]. Hydrogen sulphide can be oxidised in the presence of oxygen and under anoxic conditions by chemoautotrophic purple sulphur bacteria [48], which use the derived energy to reduce carbon dioxide $[52,55,56]$. This metabolic process is referred to as bacterial sulphate reduction. According to Deng et al. [57], sulphur-reducing bacteria are the key biological producers of $\mathrm{H}_{2} \mathrm{~S}$. These bacteria are particularly abundant in the top layer of the hydrogen sulphide zone in meromictic lakes [54], which may explain the presence of a 1-2 m redox zone devoid of oxygen and hydrogen sulphide that was observed in Lake Starodworskie during summer stagnation.

According to Nedwell and Floodgate [58], in a temperature range of $5-10^{\circ} \mathrm{C}$, hydrogen sulphide is mainly produced during the transformation of organic sulphur compounds, mostly cysteine [57]. In Lake Starodworskie, these processes may be the main source of hydrogen sulphide, because the temperature in the deepest layers usually exceeds $5{ }^{\circ} \mathrm{C}$. Lake Starodworskie has been enriched with 15 tons of aluminium sulphate. Over the years, a systematic decrease in the content of sulphates has been observed as a result of their reduction to hydrogen sulphide under anaerobic conditions. A reduction in the amount of hydrogen sulphide, which is released into the atmosphere as a result of gas convection and erosion of monimolimnion, has also been observed [2,3]. In the lake under study, distinct changes in the structure of bacterial plankton at a depth of $15 \mathrm{~m}$ (e.g., a high proportion of large, rod-shaped sulphur-reducing bacteria [8] that are characteristic of meromictic lakes or lakes with an anoxic hypolimnion [59] were observed) indicate that environmental and trophic conditions remained stable between the depth of $15 \mathrm{~m}$ and the lake bottom. The analysed lake was abundant in organic matter. The organic matter content of the monimolimnion was estimated to be $40 \%$ based on $\mathrm{BOD}_{5}$ values, which confirms that the decomposition of algal biomass stimulated hydrogen sulphide production by sulphur-reducing bacteria [60].

The soluble portion of TOC (DOC) varied on a seasonal basis, and its concentration was lower between autumn and spring and higher in the summer. A similar trend was reported by Dunalska et al. [61] in Lake Zapadłe, where DOC levels peaked in June. According to Dawson et al. [62], this could be attributed to the higher inflow of organic matter in the spring and the increased biological activity due to the higher temperature in the summer. The aforementioned authors also noted a relationship between DOC content and catchment type. In a study of Finnish lakes, Kortelainen [63] observed a close correlation between TOC and COD-Mn, water colour, iron, total nitrogen, and total phosphorus levels. Similar to Lake Zapadłe, TOC was correlated with $\mathrm{N}\left(\mathrm{r}^{2}=0.383^{* *} ; \mathrm{n}=78\right)$ in Lake Starodworskie.

\section{Conclusions}

The present study demonstrated that Lake Starodworskie was a permanently stratified water body. The lake was composed of permanent mixolimnion (comprising the epilimnion, metalimnion, and a part of the hypolimnion), monimolimnion layers determined by thermal gradients, and a chemocline layer. The chemocline was identified based 
on the distribution of electrolytic conductivity values in the hypolimnion. The chemocline was located in an anoxic zone above the thermally isolated monimolimnion. The temperature of the chemocline was somewhat elevated, which increased water density and slowed the sedimentation of chemical compounds. The chemocline was a chemically stratified layer that mainly differed in terms of the distribution of organic matter and major ions.

The use of aluminium sulphate for lake restoration with deoxygenated hypolimnion does not lead to a permanent increase in the content of sulphur compounds-the effect observed in Lake Starodworskie was temporary, as the $\mathrm{H}_{2} \mathrm{~S}$, which originated from the reduction in sulphates, was most likely released into the atmosphere as a result of monimolimnion erosion. In this type of lake, new generation coagulants, e.g., polyaluminium chloride should be used, they are active in anaerobic conditions and do not generate toxic hydrogen sulphide. The monimolimnion, to some extent, plays a protective (but not preventing) role-it protects the lake against the internal load of nutrients released from bottom sediments. Nitrogen and phosphorus stored in this water layer can be included in the cycle only as a result of monimolimnion erosion, which plays a minor role in the case of limited water dynamics. Stratification in a meromictic lake is not a static phenomenon, as evidenced by the changing range of the monimolimnion and the differences in the concentrations of chemical components of water between years. Observed chemical parameters concentration changes in the deeper part of lake were very slow, which was also confirmed by statistical analysis. This fact emphasises the neccesity of a multiannual analysis for meromicic lake studies.

Author Contributions: Conceptualization R.T. and R.A.; methodology R.T.; software R.A.; validation R.A. and J.K.G.; investigation R.T. and M.Ł.; writing—original draft preparation R.T.; writing—review and editing R.T., J.K.G., R.A. and M.Ł.; supervision J.K.G.; funding acquisition R.T. All authors have read and agreed to the published version of the manuscript.

Funding: Project financially supported by the Minister of Education and Science in the range of the program entitled "Regional Initiative of Excellence" for the years 2019-2022, Project No. 010/RID/2018/19, with the amount of funding equal to 12.000.000 PLN.

Institutional Review Board Statement: Not applicable.

Informed Consent Statement: Not applicable.

Data Availability Statement: Data are available from the Department of Water Protection Engineering and Environmental Microbiology, University of Warmia and Mazury in Olsztyn.

Acknowledgments: The authors thank Katarzyna Parszuto for help with the laboratory analysis.

Conflicts of Interest: The authors declare no conflict of interest. The funders had no role in the design of the study; in the collection, analyses, or interpretation of data; in the writing of the manuscript, or in the decision to publish the results.

\section{References}

1. Choiński, A. An Outline of Poland's Physical Limnology; UAM Press: Poznań, Czech Republic, 1995; p. 298.

2. Boehrer, B.; Schultze, M. Stratification of lakes. Rev. Geophys. 2008, 46. [CrossRef]

3. Boehrer, B.; von Rohden, C.; Schultze, M. Physical Features of Meromictic Lakes: Stratification and Circulation. In Ecology of Meromictic Lakes; Springer: Cham, Switzerland, 2017; pp. 15-34.

4. Gulati, R.D.; Zadereev, E.; Degermendzhi, A.G. (Eds.) Ecology of Meromictic Lakes; Ecological Studies; Springer: Cham, Switzerland, 2017; Volume 228, 405p.

5. Hutchinson, G.E. Treatise on Limnology: Geography, Physics and Chemistry; Wiley: New York, NY, USA, 1957 ; Volume 1.

6. Hakala, A. Meromixis as a part of lake evolution-Observations and a revised classification of true meromictic lakes in Finland. Boreal Environ. Res. 2004, 9, 37-53.

7. Hrdinka, T.; Šobr, M. Manifestation and causes of meromixis in a lake resulting from mineral extraction in Czechia. Geographie 2010, 1156, 96-112. [CrossRef]

8. Hrdinka, T.; Šobr, M.; Fott, J.; Nedbalova, L. The unique enviromnent in the most acidifield permanently meromictic lake in the Czech Republic. Limnologica 2013, 43, 417-426. [CrossRef]

9. Tandyrak, R. Evolution of Mictic and Trophic State of Lake Starodworskie on the Background of Climate and Urbanization; University of Warmia and Mazury Press: Olsztyn, Poland, 2017; Volume 205, 118p. 
10. Kubiak, J.; Machula, S.; Choiński, A. Particular example of meromixis in the anthropogenic reservoir. Carpathian J. Earth Environ. Sci. 2018, 13, 5-13. [CrossRef]

11. Januszkiewicz, T. Hydrochemical Research of Lake Klasztorne as a Sewage Receiver; Institute of Water Management Press: Rome, Italy, 1969; Volume 5, pp. 43-81.

12. Galas, J. Limnological study on a Lake Formed in a Limestone Quarry (Kraków, Poland) I. Water Chemistry. Pol. J. Environ. Stud. 2003, 12, 297-300.

13. Kraska, M.; Klimaszyk, P.; Piotrowicz, R. Meromictic Lake Czarne in the Drawieński National Park. Oceanol. Hydrobiol. Stud. 2006, 35, 55-67.

14. Tandyrak, R.; Teodorowicz, M.; Grochowska, J. Observations of selected chemical components of meromictic Lake Zapadłe waters in 1990-1993, 2000-2001 and 2005-2006. Arch. Environ. Prot. 2010, 36, 75-82.

15. Patalas, K. Water mixing as a factor determining the intensity of matter circulation in morphologically different lakes in the vicinity of Wegorzewo. Ann. Agric. Sci. 1960, 77, 233.

16. Aeschbach-Hertig, W.; Homer, M.; Schmid, M.; Kipfer, R.; Imboden, M. The physical structure and dynamics of a deep, meromictic crater lake (Lac Pavin, France). Hydrobiologia 2002, 487, 111-136. [CrossRef]

17. Melack, J.M.; Jellison, R. Limnological conditions in Mono Lake: Contrasting monomixis and meromixis in the 1990s. Hydrobiologia 1998, 384, 21-39. [CrossRef]

18. Degermendzhy, A.G.; Zadereev, E.S.; Rogozin, D.Y.; Prokopkin, I.G.; Barkhatov, Y.V.; Tolomeev, A.P.; Gulati, R.D. Vertical stratification of physical, chemical and biological components in two saline lakes Shira and Shunet (South Siberia, Russia). Aquat. Ecol. 2010, 44, 619-632. [CrossRef]

19. Torres-Talamante, O.; Alcocer, J.; Beddows, P.A.; Escobar-Briones, E.G.; Lugo, A. The key role of chemolimnion in meromictic cenotes of the Yucatan Peninsula, Mexico. Hydrobiologia 2011, 677, 107-127. [CrossRef]

20. Dietz, S.; Lessmann, D.; Boehrer, B. Contribution of Solutes to Density Stratification in a Meromictic Lake (Waldsee/Germany). Mine Water Environ. 2012, 31, 129-137. [CrossRef]

21. Tylmann, W.; Szpakowska, K.; Ohlendorf, C.; Woszczyk, M.; Zolitschka, B. Conditions for deposition of annually laminated sediments in small meromictic lakes: A case study of Lake Suminko (northern Poland). J. Paleolimnol. 2012, 47, 55-70. [CrossRef]

22. Górniak, D.; Tandyrak, R.; Parszuto, K. Relationships between physico-chemical and microbiological parameters in the monimolimnion of a forest meromictic lake. J. Limnol. 2014, 73, 511-522. [CrossRef]

23. Rodrigo, M.A.; Miracle, M.R.; Vicente, E. The meromictic Lake La Cruz (Central Spain). Patterns of stratification. Aquat. Sci. 2001, 63, 406-416. [CrossRef]

24. Tartari, G.; Copetti, D.; Franzetti, A.; Balordi, M.; Salerno, F.; Thakuri, S.; Leoni, B.; Chiarello, G.; Cristiani, P. Manganese-mediated hydrochemistry and microbiology in a meromictic subalpine lake (Lake Idro, Northern Italy)—A biogeochemical approach. Sci. Total Environ. 2021, 795, 148743. [CrossRef] [PubMed]

25. Read, J.S.; Hamilton, D.P.; Jones, I.D.; Muraoka, K.; Winslow, L.A.; Kroiss, R.; Wu, C.H.; Gaiser, E. Derivation of lake mixing and stratification indices from high-Resolution lake buoy data. Environ. Model. Softw. 2011, 26, 1325-1336. [CrossRef]

26. Schultze, M.; Boehrer, B.; Wendt-Potthoff, K.; Katsev, S.; Brown, E.T. Chemical Setting and Biogeochemical Reactions in Meromictic Lakes. In Ecology of Meromictic Lakes; Springer: Cham, Switzerland, 2017; pp. 35-59.

27. Chan, Y.F.; Chiang, P.W.; Tandon, K.; Rogozin, D.; Degermendzhi, A.; Zykov, V.; Tang, S.L. Spatiotemporal Changes in the Bacterial Community of the Meromictic Lake Uchum, Siberia. Microb. Ecol. 2021, 81, 357-369. [CrossRef] [PubMed]

28. Paschalski, J. Bradymixsis of Lake Starodworskie; High School of Agriculture Press: Olsztyn, Poland, 1963; 60p.

29. Lossow, K.; Gawrońska, H. Changes in thermal and oxygen settings in an artificially aerated lake. Arch. Environ. Prot. 1976, 2, 151-166.

30. Lossow, K.; Gawrońska, H.; Jaszczułt, R. Attempts to use wind energy for artificial destratification for Lake Starodworskie. Pol. J. Environ. Stud. 1998, 7, 221-227.

31. Gawrońska, H. Exchange of Phosphorus and Nitrogen Between Sediment and Water in an Artificially Aerated Lake; High School of Agriculture Press: Olsztyn, Poland, 1994; Volume 19, pp. 3-49.

32. Tandyrak, R. Investigation of the Effectiveness of the Lake Starodworskie Restoration by Phosphorus Inactivation Method. Ph.D. Thesis, University of Warmia and Mazury, Olsztyn, Poland, 2000.

33. Tandyrak, R. Effect of Lake Starodworskie treatment by phosphorus inactivation on the primary production properties. Pol. J. Nat. Sci. 2004, 17, 491-501.

34. Tandyrak, R. Chemism of bottom sediments from a lake treated with various restoration techniques. Electron. J. Pol. Agric. Univ. 2005, 8, 73 .

35. Augustyniak, R.; Tandyrak, R.; Łopata, M.; Grochowska, J.K. Long term sediment modification method in meromictic lake (Starodworskie Lake, Olsztyn, Poland). Land 2021, 10, 411. [CrossRef]

36. Tibco Software Inc. Statistica Software Package 13.0; Tibco Software Inc.: Palo Alto, CA, USA, 2018.

37. Zar, J.H. Biostatistical Analysis; Prentice Hall: Upper Saddle River, NJ, USA, 1984.

38. Meals, D.W.; Spooner, J.; Dressing, S.A.; Harcum, J.B. Statistical Analysis for Monotonic Trends, Tech Notes 6, November 2011. Developed for U.S. Environmental Protection Agency by Tetra Tech, Inc., Fairfax, VA, USA, 23p. 2011. Available online: https:/ / www.epa.gov/ polluted-runoff-nonpoint-source-pollution/nonpoint-source-monitoringtechnical-notes (accessed on 7 September 2021). 
39. Henry, R.; Barbosa, F.A.R. Thermal structure, heat content and stability of two lakes in The National Park of Rio Doce Vally (Minas Gerais, Brazil). Hydrobiologia 1989, 179, 189-199. [CrossRef]

40. Tandyrak, R.; Gawrońska, H. The influence of Urban Development on the Water Mass Dynamic in a Lake. Pol. J. Environ. Stud. 2009, 3, 81-86.

41. Ambrosetti, W.; Barbanti, L. Temperature, heat content, mixing and stability in Lake Orta: A pluriannual investigation. J. Limnol. 2001, 60, 60-68. [CrossRef]

42. Ambrosetti, W.; Barbanti, L. Evolution towards meromixcis of Lake Iseo (Northern Italy) as revealed by its stability trend. J. Limnol. 2005, 64, 1-11. [CrossRef]

43. Walker, K.F. The stability of meromictic lakes in central Washington. Limnol. Oceanogr. 1974, 19, 209-222. [CrossRef]

44. Wüest, A.; Piepke, G.; Halfman, J.D. Combined Effects of Dissolved Solids and Temperature on the Density Stratification of Lake Malawi. In The Limnology, Climatology and Paleoclimatology of the East African Lakes; Routledge: Abingdon-on-Thames, UK, 2019; pp. 183-202.

45. Lange, W. Methods of Physico Limnological Research; University of Gdańsk Press: Gdańsk, Poland, 1993; pp. 67-108.

46. Grochowska, J. Circulation of Selected Macroelements in the River-Lake System on the Example of the Upper Pastęka; The Committee of Environmental Engineering Press: Lublin, Poland, 2015; 181p.

47. Gulati, R.D.; Zadereev, E.S. Conclusion: Ecology of Meromictic Lakes. In Ecology of Meromictic Lakes; Springer: Cham, Switzerland, 2017; pp. 379-398.

48. Cloern, J.E.; Cole, B.E.; Oremland, R.S. Autotrophic processes in meromictic Big Soda Lake, Nevada. Limnol. Oceanogr. 1983, 28, 1049-1061. [CrossRef]

49. Rogozin, D.Y.; Tarnovsky, M.O.; Belolipetskii, M.; Zykov, V.V.; Zadereev, E.S.; Tolomeev, A.P.; Kolmakova, A.A. Disturbance of meromixis in saline Lake Shira (Siberia, Russia): Possible reasons and ecosystem response. Limnol. Ecol. Manag. Inland Waters 2017, 66, 12-23. [CrossRef]

50. Czeczuga, B. Wądołek-A holomictic lake. Acta Hydrobiol. 1966, 8, 1-4.

51. Jézéquel, D.; Michard, G.; Viollier, E.; Agrinier, P.; Albéric, P.; Lopes, F.; Bergonzini, L. Carbon Cycle in a Meromictic Crater Lake: Lake Pavin, France. In Lake Pavin; Sime-Ngando, T., Boivin, P., Chapron, E., Jezequel, D., Meybeck, M., Eds.; Springer: Cham, Switzerland, 2016. [CrossRef]

52. Tandyrak, R.; Lizuraj, M. Multiannual observations of iron and sulphur content in the waters of recultivated Lake Starodworskie, with comparision to physical and chemical parameters. Limnol. Rev. 2008, 8, 129-136.

53. Bartoszek, L. Phosphorus Release from Bottom Sediment; Rzeszow University of Technology Press: Rzeszow, Poland, 2007; 240p.

54. Jefferson, B.; Hurst, A.; Stuetz, R.; Parsons, S.A. A comparison of chemical methods for the control of odours in wastewater. Process Saf. Environ. Prot. 2002, 80, 93-99. [CrossRef]

55. Rheinheimer, G. Microbiology of Water; PWR and L Warsaw Press: Warsaw, Poland, 1987.

56. Schlegel, G.H. Total Microbiology; PWN Warsaw Press: Warsaw, Poland, 2001.

57. Deng, Q.; Wu, X.; Wang, Y.; Liu, M. Activity characteristics of sulphate reducing bacteria and formation mechanism of hydrogen sulphide. Appl. Ecol. Environ. Res. 2018, 16, 6369-6383. [CrossRef]

58. Nedvell, D.B.; Floodgate, G.D. Temperature induced changes in the formation of sulphide in marine sediment. Mar. Biol. 1972, 14, 18-24. [CrossRef]

59. Salmaso, N. Effects of habitat partitioning on the distribution of bacterioplankton in deep lakes. Front. Microbiol. 2019, 10, 2257. [CrossRef] [PubMed]

60. Achá, D.; Guédron, S.; Amouroux, D.; Point, D.; Lazzaro, X.; Fernandez, P.; Sarret, G. Algal Bloom Exacerbates Hydrogen Sulphide and Methylmercury Contamination in the Emblematic High-Altitude Lake Titicaca. Geosciences 2018, 8, 438. [CrossRef]

61. Dunalska, J.; Górniak, D.; Teodorowicz, M.; Gąsecka, K. Seasonal Distribution of Dissolved and Particulate Organic Carbon in the Water Column of a Meromictic Lake. Pol. J. Environ. Stud. 2004, 13, 375-379.

62. Dawson, J.J.C.; Malcolm, I.A.; Middlemas, S.J.; Tetzlaff, D.; Soulsby, C. Is the composition of dissolved organic carbon changing in upland acidic streams? Environ. Sci. Technol. 2009, 43, 7748-7753. [CrossRef]

63. Kortelainen, P. Content of total organic carbon in Finnish lakes and its relationship to catchment characteristics. Can. J. Fish. Aquat. Sci. 1993, 50, 1477-1483. [CrossRef] 